\title{
SERUM RETINOL BINDING PROTEIN (RBP) IBU MENYUSUI DAN BAYINYA DI DUA KABUPATEN DI JAWA BARAT
}

\section{Serum Retinol Binding Protein of Lactating Mothers and Infants at Two Districts in West Java}

\author{
Sandjaja, Sudikno \\ Pusat Penelitian dan Pengembangan Upaya Kesehatan Masyarakat, Balitbangkes, Kemenkes RI \\ Jl. Percetakan Negara No.29 Jakarta \\ E-mail:san_gizi@yahoo.com
}

\begin{abstract}
Serum retinol concentration is commonly used to determine vitamin A status. Studies show that serum retinol binding protein (RBP) is a surrogate measure of vitamin $A$. Infant is among groups of high risk in vitamin A deficiency (VAD). Studies show that vitamin A status in lactating mother are associated with that in infant. However, there is no study of association between serum RBP in mother and infant. The objective of this paper is to determine the association of serum RBP in mother and that in infant. The study was conducted at 2 districts in West Java province of 293 pairs lactating mother and breastfed infant aged 6-11 month old of poor families. Serum vitamin A and RBP were measured by HPLC and ELISA respectively. Linear regression was employed to determine association between serum RBP of infant and mother after controlling for other risk factors. Mother's serum retinol $(\mathrm{X}+\mathrm{SE})$ was higher compared to infant $(39.0+1.1$ and $29.9 \pm 0.7 \mathrm{mg} / \mathrm{dL})$. Mother's serum RBP was also higher in mother than in infant $(1.25 \pm 0.02$ and $0.95 \pm 0.01 \mu \mathrm{mol} / \mathrm{L})$. There was a significant association between serum retinol and RBP of mother $(r=0.565, p=0.000)$ and also in infant $(r=0.309, p=0.000)$. There is a significant association between RBP status of mother and infant $(r=0.379, p=0.000)$ controlled by household, mother, and child characteristics. Two main significant factors associated with serum RBP level in infant are serum RBP level of mother $(p=0.000)$ and infant received high-dose vitamin $A$ capsule $(p=0.010)$. The conclusion is that serum RBP can be used as a surrogate measure of vitamin A status and significant association between serum RBP in lactating mother and her infant.
\end{abstract}

Keywords: retinol binding protein, serum retinol, lactating mother, infant

\section{ABSTRAK}

Serum retinol umum digunakan untuk menentukan status kurang vitamin A (KVA). Salah satu alternatif menilai KVA adalah serum retinol binding protein (RBP). Beberapa penelitian membuktikan korelasi antara serum retinol ibu menyusui dan bayinya, tetapi belum ada yang meneliti korelasi RBP ibu dan bayinya. Penelitian ini bertujuan untuk mengetahui korelasi serum RBP ibu menyusui dan RBP bayi. Penelitian dilakukan di dua kabupaten di Jawa Barat dengan sampel 293 pasangan ibu menyusui dan bayinya. Serum retinol ditentukan dengan metoda HPLC sedangkan RBP dengan ELISA. Analisis regresi linier digunakan untuk menilai korelasi RBP ibu dan bayi dikontrol dengan faktor risiko lain. Kadar serum retinol $(X+S E)$ ibu menyusui lebih tinggi dibanding bayi $(39,0 \pm 1,1$ and $29,9+0,7 \mathrm{mg} / \mathrm{dL})$. RBP ibu menyusui juga lebih tinggi dibanding RBP bayi $(1,25 \pm 0,02$ and $0,95 \pm 0,01 \mu \mathrm{mol} / \mathrm{L})$. Ada korelasi signifikan antara serum retinol dengan RBP baik pada ibu menyusui $(r=0,565 ; p=0,000)$ maupun pada bayi $(r=0,309$; $p=0,000)$. Korelasi signifikan dibuktikan antara kadar RBP ibu menyusui dan RBP bayi $(r=0,379 ; p=0,000)$ dikontrol karakteristik rumahtangga, ibu, dan bayi. Faktor utama yang signifikan menentukan kadar RBP bayi adalah RBP ibu menyusui $(p=0,000)$ dan bayi menerima kapsul vitamin $A 6$ bulan terakhir $(p=0,010)$. Serum RBP merupakan alternatif menentukan KVA dan ada korelasi signifikan antara serum RBP ibu menyusui dan bayi.

Kata kunci: retinol binding protein, serum retinol, ibu menyusui, bayi 


\section{PENDAHULUAN}

W HO1 memperkirakan sebanyak 163 juta anak menderita kurang vitamin $A$ (KVA) dengan kriteria serum retinol darah $<20 \mu \mathrm{g} / \mathrm{dL}$ atau $<0,7 \mu \mathrm{mol} / \mathrm{L}$. KVA merupakan salah satu kurang gizi yang masih terjadi di negara berkembang sampai dengan saat ini. Survei pertama tingkat nasional di Indonesia tahun 1978 menunjukkan prevalensi xerophthalmia (X1B) 1,33 persen dengan range $0,55-2,34$ persen, lebih tinggi dari acuan WHO untuk menilai masalah KVA secara klinis². Sesudah mengetahui masalah KVA tersebut, Indonesia melaksanakan program distribusi kapsul vitamin A dosis tinggi untuk anak 6-59 bulan dan ibu nifas ${ }^{3}$. Survai nasional tahun 1992 menunjukkan prevalensi xerophthalmia turun dari 1,33 persen (1978) menjadi 0,34 persen ${ }^{2}$ dengan diterapkannya program kapsul vitamin A dosis tinggi untuk anak 6-59 bulan dan ibu nifas. ${ }^{3}$

Studi yang dilakukan oleh Puslitbang Gizi tahun 2006 di 10 provinsi menunjukkan prevalensi xerophthalmia 0,13 persen dan index serum retinol $<20 \mu \mathrm{g}$ pada balita sebesar 14,6 persen. ${ }^{4}$ Studi berikutnya SEANUTS tahun 2011 pada anak umur 0.5-12 tahun menunjukkan prevalensi antara $0-4,9$ persen. ${ }^{5}$ Studi dalam tulisan ini adalah studi data dasar sebagai persiapan fortifikasi minyak goreng dengan vitamin A di dua kabupaten yaitu Tasikmalaya dan Ciamis tahun 2011 menunjukkan rata-rata kadar serum vitamin A antara 30,7 - 42,7 $\mu \mathrm{g} / \mathrm{dL} .^{6}$

Studi di Tasikmalaya dan Ciamis tersebut mengumpulkan data serum retinol dan retinol binding protein (RBP) pasangan ibu menyusui dan bayinya umur 6-11 bulan. , anak balita, anak usia sekolah 6-9 tahun dan wanita usia subur. Hasil analisis lanjut menunjukkan terdapat korelasi positif signifikan $(r=0,55)$ antara status vitamin $A$ ibu menyusui dan status vitamin A bayinya. Semakin tinggi serum vitamin $A$ ibu menyusui semakin tinggi serum vitamin $A$ bayinya. Risiko bayi kurang vitamin $A$ lebih tinggi 17,5 kali $(95 \% \mathrm{Cl} 7,2-42.5)$ jika ibu menyusui juga menderita kurang vitamin A. ${ }^{7}$

Sampai dengan saat ini batasan yang digunakan oleh WHO untuk KVA adalah serum retinol. Ada dua kelompok kriteria penentuan KVA pertama secara biologi, fungsional tubuh dan histologi. Termasuk dalam kriteria pertama ini adalah buta senja, tanda dan gejala klinis, Kriteria kedua adalah secara biokimia yaitu cadangan vitamin A dalam hati, serum retinol, retinol dalam air susu ibu (ASI), RBP, relative dose response (RDR), modified relative dose response (MRDR), dilusi isotop retinol. ${ }^{8}$ Penelitian de $\mathrm{Pee}^{9}$ menunjukkan hubungan yang erat antara serum retinol dan RBP akan tetapi datanya masih terbatas dan belum konklusif serta terbatas pada anak umur 6-71 bulan. Tulisan ini bertujuan untuk menambah analisis hubungan antara serum retinol dan RBP pada ibu menyusui dan bayi. Tujuan kedua adalah untuk analisis hubungan antara RBP antara ibu menyusui dan bayinya yang belum ada penelitian tentang hal ini. Yang sudah dilakukan adalah hubungan antara serum retinol ibu menyusui dan bayinya. ${ }^{7}$

\section{METODE PENELITIAN}

Studi ini merupakan bagian dari studi data dasar fortifikasi vitamin A dalam minyak goreng curah yang dilakukan di dua kabupaten yaitu Tasikmalaya dan Ciamis. Pemilihan dua kabupaten tersebut dilakukan secara purposif dengan kriteria konsumsi minyak goreng curah cukup tinggi dibanding minyak goreng kemasan, konsumsi minyak goreng yang difortifikasi vitamin A cukup tinggi, lebih banyak proporsi penduduk dengan sosial ekonomi rendah. Di kabupaten tersebut masing-masing dipilih 4 kecamatan, di masing-masing kecamatan dipilih 3 desa. Di desa dipilih keluarga gakin dari daftar yang diberikan oleh pihak Dinas Kesehatan. Keluarga sampel terpilih adalah pasangan ibu menyusui dengan bayinya berumur 6-11 bulan.

Jumlah sampel pasangan ibu menyusui dan bayinya dihitung berdasarkan rumus perbedaan peningkatan kadar serum retinol setelah fortifikasi vitamin A dalam minyak goreng. Asumsi rata-rata serum retinol ibu menyusui dan bayi masing-masing sebesar $26,0 \pm 11,0 \mu \mathrm{g} / \mathrm{dL}$ dan $20,0 \pm 5,0 \mu \mathrm{g} / \mathrm{dL}$, tingkat kepercayaan 95 persen dan power 80 persen. Dari dua perhitungan tersebut, jumlah sampel yang terbanyak yang diambil.

Pengumpulan data dilakukan oleh enumerator yaitu tenaga gizi Puskesmas setempat yang telah mendapatkan pelatihan oleh Tim peneliti. Enumerator mengumpulkan data karakteristik keluarga dan tingkat sosial ekonomi keluarga, karakteristik ibu dan bayinya, 
morbiditas, paritas ibu dan riwayat kelahiran bayi, konsumsi makanan bayi dengan menggunakan kuesioner yang sudah dilakukan pre-test. Kriteria inklusi adalah ibu dan bayinya dalam keadaan sehat dalam pemeriksaan klinis oleh dokter setempat, tidak ada indikasi kelainan untuk pengambilan darah, umur bayi antara 6-11 bulan, ibu menyusui bayinya. Kriteria eksklusi adalah bayi tidak pernah mendapatkan ASI atau sudah disapih, tidak sehat, dan ada indikasi kelainan saat pengambilan darah. Selain ASI, konsumsi makanan bayi dilakukan dengan dietary recall 2 x 24 jam. Enumerator dibekali dengan timbangan makanan agar bisa lebih akurat dalam memperkirakan berat makanan terutama untuk makanan lokal yang dikonsumsi. Berat zat gizi makanan dengan menggunakan Tabel Komposisi Bahan Makanan ${ }^{10}$, kemudian entry data dilakukan dengan menggunakan pogram Nutrisoft. ${ }^{11}$ Analisis data konsumsi vitamin A untuk mengetahui nilai rata-rata dan proporsi yang mengonsumsi vitamin A kurang dari Angka Kecukupan Gizi. ${ }^{12}$

Pengumpulan spesimen darah untuk retinol binding protein (RBP) dan serum retinol dilakukan oleh tenaga plebotomis dari Laboratorium "P" setempat yang telah mendapatkan penjelasan dari Tim peneliti. Spesimen darah diambil dari vena cubiti untuk ibu menyusui dan dari vena tungkai untuk bayi sebanyak masing-masing $5 \mathrm{~mL}$ dengan menggunakan vacutainer mengandung EDTA. Vacutainer disimpan dalam cool box selama pengumpulan specimen darah di lapangan. Spesimen darah segera dipisahkan untuk mendapatkan plasma dengan sentrifuse. Serum dibagi ke dalam beberapa aliquote dan disimpan dalam suhu $-20^{\circ} \mathrm{C}$. Aliquote dikirim ke Laboratorium di Jerman untuk analisis RBP dan serum retinol. Analisis RBP dilakukan dengan metode teknik sandwich ELISA. ${ }^{13}$

Penelitian ini sudah mendapatkan ijin etik penelitian dari Komisi Etik, Badan Litbang Kesehatan nomor KE 01.05/EC/262/2011 tanggal 3 Mei 2011. Sebelum pengumpulan data dilakukan sudah mendapatkan informed consent dari sampel ibu menyusui yang disaksikan oleh kader desa atau aparat desa setempat.

Semua data di-input dalam komputer dengan menggunakan program Foxpro yang didesain khusus sesuai dengan variabel yang dikumpulkan. Sebelum analisis data, dilakukan pengecekan konsistensi semua variabel yang dianalisis. Sampel ibu menyusui dan atau bayi yang tidak mempunyai data utama yaitu RBP tidak dimasukkan dalam analisis. Analisis deskriptif dilakukan untuk mengetahui karakteristik rumahtangga, ibu menyusui, bayi, borbiditas bayi, RBP, serum retinol, dan variabel kovariat yang berpotensi mempengaruhi status RBP ibu dan bayinya. Analisis regresi multivariat dilakukan untuk mengetahui hubungan antara RBP bayi sebagai dependen variabel dengan RBP ibu menyusui yang dikontrol oleh kovariat. Penyajian data dilakukan dalam bentuk tabel dan gambar.

\section{HASIL}

Jumlah sampel yang berhasil dianalisis 293 pasangan ibu menyusui dan bayinya. Karakteristik rumahtangga sampel terlihat dalam Tabel 1. Sesuai dengan kriteria inklusi yaitu rumahtangga miskin, pendidikan kepala keluarga sebagian besar hanya tamat SMP atau lebih rendah. Lebih dari separuh kepala keluarga bekerja sebagai petani atau buruh. Lebih dari 80 persen keluarga sampel dengan status sosial ekonomi pada kelompok kuintil-1 dan kuintil 2.

Pada Tabel 2 disajikan karakteristik ibu menyusui. Umur paling muda ibu menyusui 17 tahun dan umur tertua 46 tahun. Bila dikelompokkan umur ibu hampir sama antara 4 kelompok umur seperti dalam tabel. Sebagian besar ibu adalah ibu rumahtangga dengan pendidikan tamat SMP ke bawah. Proporsi gravida paling banyak ibu primipara, sedangkan gravida paling tinggi adalah tujuh. Sebagian besar ibu tidak pernah mengalami keguguran. Status gizi ibu menunjukkan bahwa sebagian besar ibu berstatus gizi baik. Tetapi sebagian ibu dengan status gizi kurus $(10,9 \%)$ dan sebagian mengalami obesitas (15,0\%).

Tabel 3 menyajikan karakteristik bayi. Terlihat bahwa umur bayi terbagi rata dari umur 6 - 11 bulan. Tidak banyak perbedaan jumlah bayi laki-laki dan perempuan. Sebagian besar bayi dilahirkan cukup bulan dengan berat badan lahir terbesar pada kelompok 3000-3499 gram. Hanya 1 dari 4 bayi menerima kapsul vitamin $\mathrm{A}$ $(24,9 \%)$ oleh karena sebagian bayi masih berumur di bawah 6 bulan saat bulan distribusi kapsul vitamin A. Penyakit paling banyak 
diderita dalam sebulan terakhir adalah ISPA, disusul dengan diare. Sedangkan penyakit lainnya tidak banyak diderita oleh bayi.

Rata-rata serum retinol ibu menyusui lebih tinggi dibanding dengan serum retinol bayi. Dengan menggunakan cut-off pont $20 \mu \mathrm{g} / \mathrm{dL}$ prevalensi KVA ibu menyusui sebesar 12,3 persen dan KVA pada bayi 19,8 persen. Rata- rata RBP ibu menyusui juga lebih tinggi dibanding RBP bayi seperti terlihat pada Tabel 4. Proporsi serum RBP ibu menyusui yang paling banyak terdapat pada kelompok antara $0,9-1,49 \mu \mathrm{mol} / \mathrm{L}$, sedangkan proporsi RBP paling banyak pada bayi antara 0,6 - 1,19 $\mu \mathrm{mol} / \mathrm{L}$ seperti terlihat dalam Tabel 5 .

Tabel 1

Karakteristik rumah tangga

\begin{tabular}{|c|c|c|c|c|c|}
\hline Variabel & $n$ & $\%$ & Variabel & $\mathrm{n}$ & $\%$ \\
\hline Pendidikan KK & & & Pekerjaan KK & & \\
\hline$\leq$ Tidak tamat SD & 8 & 2,7 & PNS/TNI/Pol/BUMN & 5 & 1,7 \\
\hline$\overline{\text { Tamat SD }}$ & 128 & 43,7 & Swasta & 104 & 35,5 \\
\hline Tamat SMP & 89 & 30,4 & Petani/ Buruh & 175 & 59,7 \\
\hline$\geq$ Tamat SLTA & 63 & 21,5 & Lain-lain & 4 & 1,4 \\
\hline $\bar{N} A$ & 5 & 1,7 & NA & 5 & 1,7 \\
\hline Jumlah anggota keluarga & & & Status sosial ekonomi & & \\
\hline 3 & 65 & 22,1 & Kuintil-1 (terendah) & 157 & 53,6 \\
\hline 4 & 86 & 29,4 & Kuintil-2 (rendah) & 78 & 26,6 \\
\hline 5 & 70 & 23,9 & Kuintil-3 (menengah) & 58 & 19,8 \\
\hline$\geq 6$ & 72 & 24,6 & & & \\
\hline
\end{tabular}

Tabel 2

Karakteristik Ibu Menyusui

\begin{tabular}{|c|c|c|c|c|c|}
\hline Variabel & $\mathrm{n}$ & $\%$ & Variabel & $n$ & $\%$ \\
\hline Umur ibu (tahun) & & & Abortus & & \\
\hline$<25$ & 83 & 28,3 & Tidak pernah & 253 & 86,3 \\
\hline $25-29$ & 68 & 23,2 & Sekali & 40 & 13,7 \\
\hline $30-34$ & 65 & 22,2 & $\geq$ Dua kali & - & - \\
\hline$\geq 35$ & 77 & 26,3 & & & \\
\hline Status ibu & & & Status gizi ibu menyusui & & \\
\hline Menikah & 286 & 97,6 & Kurus & 32 & 10,9 \\
\hline Cerai hidup/ mati & 2 & 2,4 & Gizi baik & 180 & 61,4 \\
\hline Pendidikan ibu & & & Gizi lebih & 35 & 12,0 \\
\hline$\leq$ Tamat SD & 139 & 47,4 & Obesitas & 44 & 15,0 \\
\hline Tamat SMP & 82 & 28,0 & Missing & 2 & 0,7 \\
\hline$\geq$ Tamat SLTA & 69 & 23,6 & & & \\
\hline NA & 3 & 1,0 & Pekerjaan ibu & & \\
\hline Gravida & & & PNS/TNI/Pol/BUMN & 3 & 1,0 \\
\hline 1 & 107 & 36,5 & Swasta & 19 & 6,5 \\
\hline 2 & 83 & 28,3 & Petani/ Buruh/dll & 9 & 3,1 \\
\hline 3 & 63 & 21,5 & Tidak bekerja & 259 & 88,4 \\
\hline$\geq 4$ & 40 & 13,7 & NA & 3 & 1,0 \\
\hline
\end{tabular}


Tabel 3

Karakteristik Bayi

\begin{tabular}{|c|c|c|c|c|c|}
\hline Variabel & $n$ & $\%$ & Variabel & $\mathrm{n}$ & $\%$ \\
\hline Umur bayi (bulan) & & & Berat badan lahir (gram) & & \\
\hline 6 & 52 & 17,7 & $<2500$ & 11 & 3,9 \\
\hline 7 & 47 & 16,0 & $2500-2999$ & 77 & 27,0 \\
\hline 8 & 54 & 18,4 & $3000-3499$ & 124 & 43,5 \\
\hline 9 & 43 & 14,7 & $3500-3999$ & 61 & 21,4 \\
\hline 10 & 45 & 15,4 & NA & 12 & 4,2 \\
\hline \multirow[t]{2}{*}{11} & 52 & 17,8 & Minum pil/ sirup & & \\
\hline & & & Kapsul vitamin A & 73 & 82,0 \\
\hline Jenis kelamin & & & Vitamin lainnya & 16 & 18,0 \\
\hline Laki-laki & 149 & 50,9 & Morbiditas & & \\
\hline \multirow[t]{2}{*}{ Perempuan } & 144 & 49,1 & ISPA & 183 & 62,2 \\
\hline & & & Pneumonia & 25 & 8,5 \\
\hline Riwayat persalinan & & & Diarrhea & 69 & 23,5 \\
\hline Cukup bulan & 281 & 95,9 & Campak & 4 & 1,4 \\
\hline Kurang bulan & 12 & 4,1 & Lainnya & 13 & 4,4 \\
\hline
\end{tabular}

Tabel 4

Serum Retinol dan RBP Ibu Menyusui dan Bayinya

\begin{tabular}{lccc}
\hline \multicolumn{1}{c}{ Variabel } & $\mathrm{n}$ & $\mathrm{X} \pm \mathrm{SD}$ & $\mathrm{SE}$ \\
\hline Serum RBP $(\mu \mathrm{mol} / \mathrm{L})$ & & & \\
Ibu menyusui & 293 & 1,25 & 0,02 \\
Bayi & 293 & 0,95 & 0,01 \\
\hline Serum retinol $(\mu \mathrm{g} / \mathrm{dL})$ & & & \\
Ibu menyusui & 293 & 39,0 & 1,1 \\
Bayi & 293 & 29,9 & 0,7 \\
\hline
\end{tabular}

Tabel 5

Kelompok RBP Ibu Menyusui dan Bayinya

\begin{tabular}{lcccc}
\hline Kelompok RBP & \multicolumn{2}{c}{$\mathrm{lbu}$} & \multicolumn{2}{c}{ Bayi } \\
\cline { 2 - 5 }$(\mu \mathrm{mol} / \mathrm{L})$ & $\mathrm{n}$ & $\%$ & $\mathrm{n}$ & $\%$ \\
\hline$<0.6$ & 1 & 0,3 & 3 & 1,0 \\
$0.60-0.89$ & 32 & 10,9 & 108 & 36,9 \\
$0.90-1.19$ & 88 & 30,0 & 123 & 42,0 \\
$1.20-1.49$ & 99 & 33,8 & 52 & 17,7 \\
$1.50-1.79$ & 47 & 16,0 & 6 & 2,0 \\
$1.80-2.09$ & 19 & 6,5 & 1 & 0,3 \\
$\geq 2.10$ & 7 & 2,4 & - & - \\
\hline Total & 293 & 100 & 293 & 100 \\
\hline
\end{tabular}


Tabel 6

Kadar RBP Bayi menurut Karakteristik Rumahtangga dan Ibu Menyusui

\begin{tabular}{|c|c|c|c|c|c|}
\hline Variabel & $\begin{array}{c}X \pm S D \\
(\mu \mathrm{mol} / \mathrm{L})\end{array}$ & $p$ & Variabel & $\begin{array}{c}X \pm S D \\
(\mu \mathrm{mol} / L)\end{array}$ & $p$ \\
\hline Kuintil SES & & & Gravida ibu & & \\
\hline Kuintil-1 & $0,94 \pm 0,23$ & 0,317 & Satu & $0,95 \pm 0,20$ & 0,556 \\
\hline Kuintil-2 & $0,98 \pm 0,22$ & & Dua & $0,95 \pm 0,23$ & \\
\hline Kuintil-3 & $0,98 \pm 0,23$ & & Tiga & $0,98 \pm 0,23$ & \\
\hline Umur ibu (tahun) & & & $\geq$ Empat & $0,92 \pm 0,26$ & \\
\hline $20-24$ & $0,96 \pm 0,20$ & 0,785 & Status gizi ibu & & \\
\hline $25-29$ & $0,93 \pm 0,22$ & & Kurus & $0,92 \pm 0,18$ & 0,753 \\
\hline $30-34$ & $0,97 \pm 0,20$ & & Normal & $0,96 \pm 0,23$ & \\
\hline$\geq 35$ & $0,96 \pm 0,27$ & & Gizi lebih & $0,95 \pm 0,25$ & \\
\hline Minum multivitamin & & & Obesitas & $0,98 \pm 0,22$ & \\
\hline $\mathrm{Ya}$ & $0,97 \pm 0,16$ & 0,931 & Ibu kurang vit $\mathrm{A}$ (KVA) & & \\
\hline Tidak & $0,95 \pm 0,23$ & & $\begin{array}{l}\text { Tidak } \\
\text { Ya }\end{array}$ & $\begin{array}{l}0,96 \pm 0,22 \\
0,89 \pm 0,26\end{array}$ & 0,089 \\
\hline
\end{tabular}

Tabel 7

Kadar RBP Bayi menurut Karakteristik Bayi

\begin{tabular}{|c|c|c|c|c|c|}
\hline Variabel & $X \pm S D$ & $p$ & Variabel & $X \pm S D$ & $p$ \\
\hline Umur bayi (bulan) & & & Sakit pneumonia & & \\
\hline $6-8$ & $0,96 \pm 0,23$ & 0,797 & Ya & $0,92 \pm 0,23$ & 0,376 \\
\hline $9-11$ & $0,95 \pm 0,22$ & & Tidak & $0,96+0,22$ & \\
\hline Jenis kelamin bayi & & & Sakit campak & & \\
\hline Laki-laki & $0,95 \pm 0,23$ & 0,684 & $\mathrm{Ya}$ & $0,92 \pm 0,23$ & 0,393 \\
\hline Perempuan & $0,96 \pm 0,22$ & & Tidak & $0,96 \pm 0,22$ & \\
\hline Berat badan lahir & & & Sakit diare & & \\
\hline$<2500$ & $0,92 \pm 0,28$ & 0,825 & $\mathrm{Ya}$ & $0,94 \pm 0,25$ & 0,695 \\
\hline $2500-2999$ & $0,97 \pm 0,25$ & & Tidak & $0,96 \pm 0,22$ & \\
\hline $3000-3499$ & $0,95 \pm 0,21$ & & Konsumsi protein & & \\
\hline$>3500$ & $0,94 \pm 0,23$ & & Cukup & $0,93 \pm 0,22$ & 0,142 \\
\hline $\begin{array}{l}\text { Menerima kapsul } \\
\text { vitamin A }\end{array}$ & & & Kurang & $0,97 \pm 0,23$ & \\
\hline $\mathrm{Ya}$ & $1,00 \pm 0,22$ & 0,014 & Konsumsi vitamin $\mathrm{A}$ & & \\
\hline Tidak & $0,93 \pm 0,23$ & & Cukup & $0,95 \pm 0,24$ & 0,665 \\
\hline Sakit ISPA & & & Kurang & $0,96 \pm 0,22$ & \\
\hline $\mathrm{Ya}$ & $0,95 \pm 0,23$ & 0,445 & Konsumsi zat besi & & \\
\hline Tidak & $0,97 \pm 0,21$ & & Cukup & $0,92+0,23$ & 0,136 \\
\hline & & & Kurang & $0,96 \pm 0,22$ & \\
\hline
\end{tabular}

Analisis uji-t dan ANOVA antara kadar RBP bayi dengan faktor risiko karakteristik rumahtangga dan ibu menyusui disajikan pada Tabel 6 . Tidak ada perbedaan yang signifikan kadar RBP menurut kuintil status sosial ekonomi, umur ibu, ibu minum multivitamin, gravida ibu, dan status gizi ibu. Kecenderungan adanya perbedaan kadar RBP bayi terlihat menurut status vitamin A ibu. Kadar RBP bayi lebih tinggi jika ibunya tidak menderita KVA dibandingkan dengan ibu yang menderita KVA walaupun tidak signifikan $(p=0,089)$.

Analisis uji-t dan ANOVA juga dilakukan untuk kadar RBP bayi dan faktor risiko karakteristik bayi yang disajikan pada Tabel 7 . Hasilnya tidak ada perbedaan signifikan kadar RBP bayi menurut umur bayi, jenis kelamin, berat badan lahir, menderita sakit ISPA, 
pneumonia, campak, diare dalan 1 bulan terakhir, konsumsi protein, vitamin $A$, dan zat besi. Faktor yang berperan signifikan dalam perbedaan kadar RBP bayi adalah bayi menerima kapsul vitamin A dalam 6 bulan terakhir. Kadar RBP bayi yang menerima kapsul vitamin A lebih tinggi secara signifikan dibanding bayi yang tidak menerima kapsul vitamin $A(p=0,014)$.

Gambar 1 menyajikan hubungan antara kadar serum retinol ibu dengan RBP ibu. Hasil analisis menunjukkan hubungan linier yang signifikan $(p=0,000)$ antara kadar retinol ibu dan RBP ibu dengan koefisien korelasi $r$ sebesar 0,565 dan koefisien determinasi $r^{2}$ sebesar 0,319 .
Gambar 2 menyajikan hubungan yang sama antara kadar serum retinol dan RBP tetapi pada bayi. Hasilnya juga menunjukkan hubungan yang signifikan $(p=0,000)$ walaupun keeratan hubungan lebih rendah dibanding pada ibu menyusui karena koefisien korelasi dan determinasi yang lebih rendah.

Hubungan antara RBP pasangan ibu menyusui dan bayinya disjikan pada Gambar 3 . Hasil analisis regresi menunjukkan hubungan yang signifikan $(p=0,000)$ antara RBP ibu menyusui dan bayinya dengan koefisien korelasi $r$ sebesar 0,351 dan koefisien determinasi $r^{2}$ sebesar 0,123 .

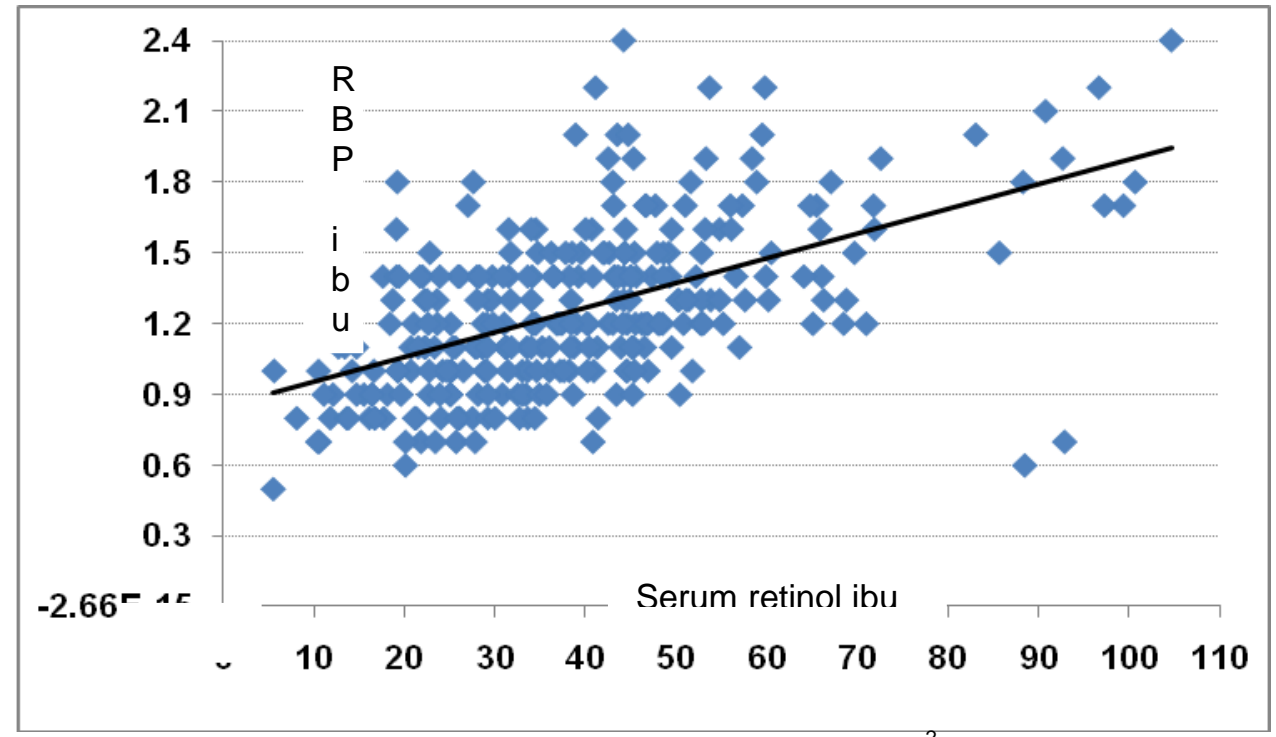

RBP ibu $=0,818+0,011$ serum retinol ibu $\left(r=0,565, r^{2}=0,319, p=0,000\right)$

Gambar 1

Hubungan antara Kadar Serum Retinol dan RBP pada Ibu Menyusui

Tabel 8

Analisis Multivariat Hubungan antara Kadar RBP Bayi dan Faktor-faktornya

\begin{tabular}{lccccc}
\hline \multicolumn{1}{c}{ Variabel dalam model } & Koefisien & Std error & Beta & $t$ & $p$ \\
\hline Konstanta & 0,786 & 0,065 & & 12,160 & 0,000 \\
RBP ibu menyusui & 0,228 & 0,035 & 0,351 & 6,468 & 0,000 \\
Bayi menerima kapsul vit. A & $-0,069$ & 0,027 & $-0,141$ & $-2,598$ & 0,010 \\
\hline
\end{tabular}

$\left(R=0,379, R^{2}=0,144, p=0,000\right)$ 


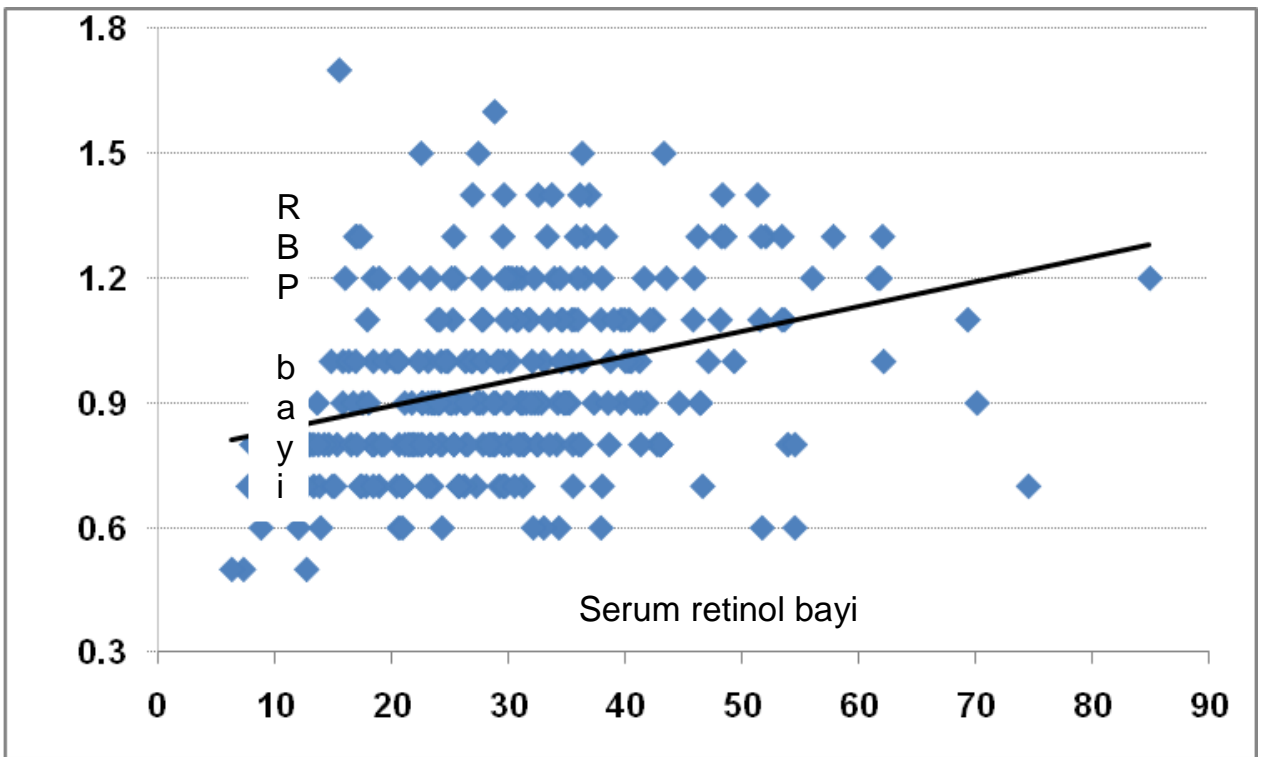

RBP bayi $=0,789+0,006$ serum retinol bayi $\left(r=0,309, r^{2}=0,096, p=0,000\right)$

Gambar 2

Hubungan antara Kadar Serum Retinol dan RBP pada Bayi

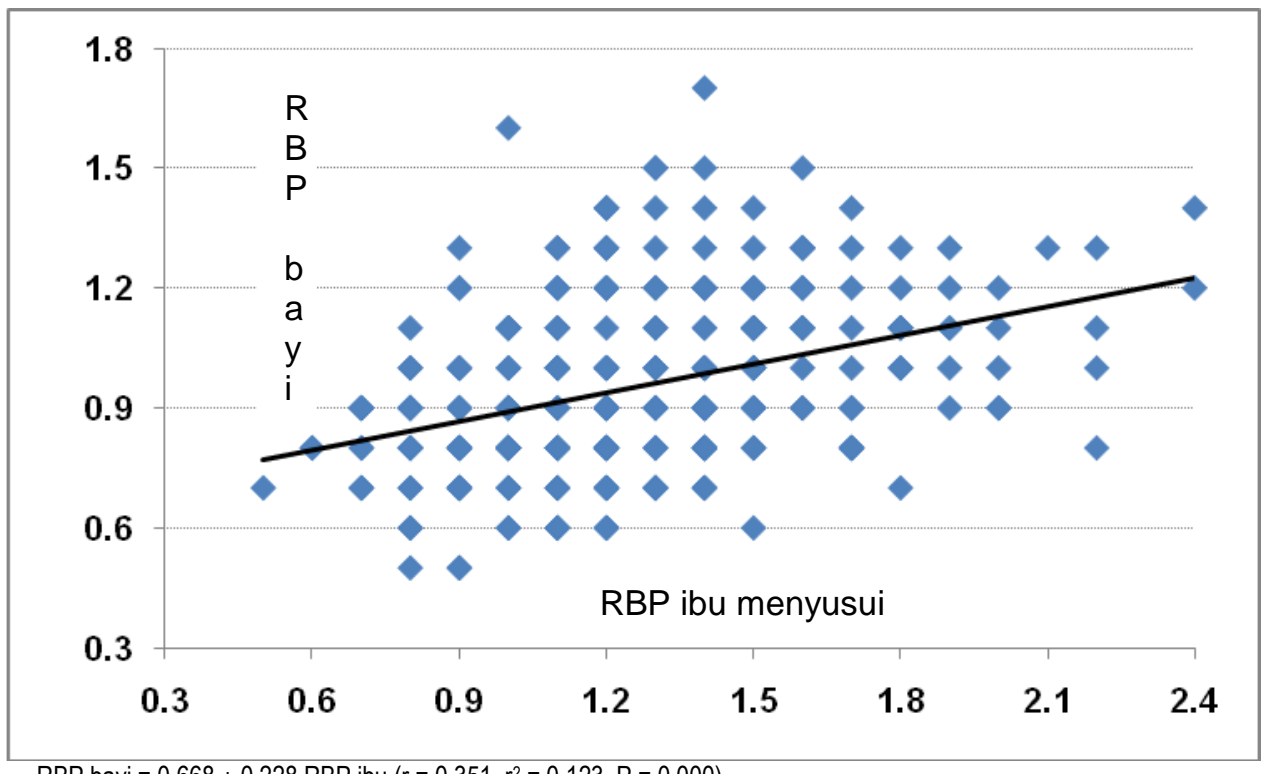

RBP bayi $=0,668+0,228$ RBP ibu $\left(r=0,351, r^{2}=0,123 . P=0,000\right)$

Gambar 3

Hubungan antara Kadar RBP Ibu Menyusui dan RBP Bayi

Dari hasil uji-t, ANOVA, dan regresi linier dengan nilai $p$ kurang dari 0,25 dimasukkan dalam model regresi ganda yaitu RBP ibu, ibu KVA, bayi menerima kapsul vitamin A dalam 6 bulan yang lalu, konsumsi protein dan zat besi. Hasil analisis regresi multivariat menunjukkan 2 faktor yang berhubungan signifikan dengan RBP bayi yaitu RBP ibu dan bayi menerima kapsul vitamin A dengan nilai $\mathrm{R}$ sebesar 0,379 dan $R^{2}$ sebesar 0,144 .

\section{BAHASAN}

Retinol binding protein (RBP) adalah sejenis protein yang mengikat retinol dan berperan penting dalam mendistribusikan retinol 
ke seluruh tubuh yang memerlukan. Oleh karena peran yang penting tersebut, sejak konsepsi retinol sudah dideteksi sejak kehamilan karena ada dalam uterus, janin. RBP disintesa dalam hati dimana kadarnya berhubungan dengan cadangan retinol. Oleh karena itu RBP merupakan refleksi atau surrogate dari kadar serum retinol. ${ }^{9}$ Penentuan kadar RBP juga mempunyai kelebihan dari serum retinol karena RBP merupakan senyawa protein yang lebih mudah analisisnya, lebih sederhana, lebih stabil terhadap suhu dan cahaya, bisa dilakukan hanya dengan pengambilan darah tepi dari ujung jari sebanyak 10-20 $\mu \mathrm{L}$ jika dibandingkan dengan retinol yang memerlukan darah vena $100 \mu \mathrm{L}$, dan lebih murah biayanya dibandingkan dengan serum retinol.., 13

RBP membawa retinol untuk janin melalui plasenta. Salah satu peran penting retinol adalah untuk pertumbuhan. Oleh karena itu peran RBP untuk transpor retinol ke janin melalui plasenta sangat menentukan pertumbuhan janin. ${ }^{9}$ Walaupun demikian status vitamin $A$ baru lahir sangat terbatas dengan cadangan vitamin $\mathrm{A}$ yang rendah. ${ }^{14}$ Oleh karena ibu bayi baru lahir sangat menggantungkan kebutuhan vitamin A dari ASI. Bahkan UNICEF menyatakan cadangan vitamin $A$ bayi lahir hanya cukup untuk beberapa hari. ${ }^{15}$ Pada masa usia bayi, sumber utama retinol berasal dari ASI. Dengan demikian RBP sebagai media transport retinol berperan krusial menentukan status vitamin A bayi terutama pada enam bulan pertama usia bayi karena sebagian besar ibu masih ASI eksklusif.

Hasil penelitian ini menunjukkan hubungan yang signifikan antara kadar retinol dan RBP pada ibu menyusui (Gambar 1). Hubungan signifikan juga ditemukan antara kadar retinol dan RBP pada bayi walaupun dengan koefisien korelasi yang lebih rendah (Gambar 2). Penelitian serupa antara serum retinol dan RBP juga ditemukan oleh peneliti lain pada era 1970an. Penelitian Smith di Mesir pada anak balita yang kurang gizi ${ }^{16,17}$, dan penelitian Ingenbleek18 juga pada balita kurang gizi menunjukkan koefisien korelasi yang tinggi antara serum retinol dan RBP yaitu antara 0,62 0,93 . Hasil penelitian ini dengan koefisien korelasi yang lebih rendah yaitu 0,56 pada ibu menyusui dan 0,31 pada bayi. Akan tetapi analisis retinol saat itu masih menggunakan metoda fluorometri sedangkan penelitian ini menggunakahn HPLC.

Sesudah itu hubungan antara serum retinol dan RBP lebih banyak ditujukan untuk mencari cut-off point RBP yang setara dengan <20 $\mu \mathrm{g} / \mathrm{dL}$ retinol dengan sensitivitas (Se) dan spesifisitas (Sp) yang cukup tinggi. Tetapi terdapat variasi cut-off point yang lebar yang setara dengan serum retinol $<20 \mu \mathrm{g} / \mathrm{dL}$. Studi di Indonesia ${ }^{19}$ pada anak umur 3-6 tahun dengan cut-off point $<0,69 \mu \mathrm{mol} / \mathrm{L}$ ( $S e=75, S p=63$ ), sedangkan studi di Kepulauan Marshall ${ }^{20}$ pada anak umur 1-5 tahun dengan cut-off point $<0,77$ $\mu \mathrm{mol} / \mathrm{L}(\mathrm{Se}=96, \mathrm{Sp}=88)$. Penelitian pada ibu hamil di Malawi ${ }^{21}$ mendapatkan cut-off point 1,00 $\mu \mathrm{mol} / \mathrm{L}(\mathrm{Se}=88, \mathrm{Sp}=95)$ dan penelitian di Indonesia ${ }^{22}$ pada ibu menyusui mendapatkan cut-off point $<1,29 \mu \mathrm{mol} / \mathrm{L}$ (Se=72, Sp=70). Penelitian di Kenya ${ }^{23}$ pada wanita umur 16-45 tahun menunjukkan koefiesien korelasi yang tinggi $(r=0,88)$ dengan cut-off point $<0,77$ $\mu \mathrm{mol} / \mathrm{L}(\mathrm{Se}=91, \mathrm{Sp}=94$ ).

Walaupun dengan nilai cut-off point dengan sebaran berbeda tetapi dengan nilai Se dan Sp yang cukup tinggi menunjukkan hubungan yang erat antara serum retinol dan RBP. Perbedaan cut-off point tersebut karena perbedaan tingkat kejenuhan (saturasi) RBP. Ada dua jenis RBP yaitu holo-RBP dan apo-RBP. Holo-RBP adalah RBP yang mengikat retinol sedangkan apo-RBP adalah RBP yang tidak sedang mengikat retinol. Semakin tinggi holo-RBP semakin tinggi tingkat kejenuhan RBP. ${ }^{9}$ Tingkat kejenuhan RBP ini bervariasi di setiap masyarakat sehingga cut-off point dari beberapa penelitian tersebut juga berbeda.

Dengan tingkat Se dan Sp yang cukup tinggi antara serum retinol dan RBP dapat disimpulkan bahwa RBP merupakan surrogate yang cukup baik untuk menilai status vitamin $A$. Tetapi semua penelitian di atas melakukan analisis hubungan antara serum retinol dan RBP. Belum ada yang melakukan analisis hubungan antara RBP ibu menyusui dan RBP banyinya. Hasil penelitian ini pada Gambar 3 menunjukkan bahwa ada korelasi positif yang signifikan antara RBP ibu menyusui dan bayinya $\left(r=0,351, r^{2}=0,123 . P=0,000\right)$. Semakin tinggi serum retinol ibu menyusui semakin tinggi RBP bayinya. Analisis regresi multivariat tetap menunjukkan kuatnya korelasi antara RBP ibu menyusui dan bayinya. Hanya 
satu variabel lain yang berperan signifikan terhadap RBP bayi yaitu bayi menerima kapsul vitamin A. Sedangkan variabel lain baik karakteristik rumahtangga, karakteristik ibu menyusui dan bayinya tidak ada korelasi yang signifikan dengan RBP. Faktor lain yang potensial berperan dalam RBP bayi yaitu ibu menyusui saat nifas menerima kapsul vitamin $A$ tidak dikumpulkan karena kuesioner untuk ibu menyusui juga digunakan untuk wanita usia subur (WUS) yang tidak sesuai jika ditanyakan karena tidak ada program distribusi kapsul vitamin A untuk WUS. Dengan hasil korelasi signifikan antara RBP bayi dengan RBP ibu menyusui dan kapsul vitamin $A$, meningkatkan status vitamin $A$ ibu menyusui yang tinggi dan cakupan distribusi kapsul vitamin A dapat menjamin status RBP dan serum retinol pada bayinya.

\section{SIMPULAN DAN SARAN}

\section{Simpulan}

Serum retinol mempunyai korelasi yang signifikan dengan kadar RBP baik pada ibu menyusui maupun pada bayi. Kadar RBP ibu menyusui mempunyai korelasi yang signifikan dengan kadar RBP bayinya setelah dikontrol oleh penerimaan kapsul vitamin A pada bayi.

\section{Saran}

Meningkatkan kadar RBP ibu menyusui, menigkatkan cakupan kapsul vitamin A pada bayi 6-11 bulan dan ibu nifas berperan penting dalam meningkatkan serum retinol dan RBP bayi.

\section{UCAPAN TERIMA KASIH}

Ucapan terima kasih penulis tujukan untuk Badan Litbang Kesehatan sebagai penyandang dana penelitian tahun 2011. Juga kepada Dinas Kesehatan Kabupaten Tasikmalaya dan Ciamis berikut jajaran sampai ke tingkat desa, Tim Peneliti, kader kesehatan dan para enumerator sehingga pelaksanaan penelitian ini dapat diselesaikan dengan baik. Tidak lupa pula bahwa penelitian ini tidak akan bisa dilakukan tanpa partisipasi sukarela sampel penelitian yaitu para ibu menyusui dan bayi di daerah penelitian.

\section{RUJUKAN}

1. United Nation, Standing Committee on Nutrition. 6th Report on the World Nutrition Situation - Progress in Nutrition. No place, UN-SCN, 2010.

2. Muhilal, H., Tarwotjo, I., Kodyat, B., Herman, S., Permaesih, D., Karyadi, D., Wilbur, S. \& Tielsch, ]. (1994) Changing prevalence of xerophthalmia in Indonesia, 1977-1992. Eur. J. Clin. Nutr. 48: 708-714.

3. Departemen Kesehatah RI. Panduan manajemen Suplementasi Vitamin A, Jakarta, Depkes, 2006.

4. Puslitbang Gizi. Laporan studi masalah gizi mikro. Bogor, Puslitbang Gizi. Laporan Penelitian, 2006.

5. Ernawati F, Sandjaja, Moesijanti MYE. Status vitamin A dan zat besi anak Indonesia. Gizi Indonesia 36 (2): 123-130, 2013.

6. Sandjaja, Jus'at I, Jahari AB, Ifrad, Htet $M K$, Tilden $R L$ et al. Vitamin $A$ fortified cooking oil reduces vitamin A deficiency in infants, young children, and women: results from a programme evaluation in Indonesia. Public Health Nutrition 2014. doi:10.1017/S136898001400322X.

7. Jus'at I, Sandjaja, Sudikno, Ernawati F. Maternal serum retinol level is a risk factor of infant's vitamin A status. Paper presented at 9th Asia Pacific Conference on Clinical Nutrition (APCCN) 2015, Kuala Lumpur 25-19 January 2015. Malaysian J Nutr 21 (Suppl): S62, 2015.

8. Tanumihardjo SA. 2011 Vitamin A: biomarkers of nutrition for development. Am. J. C,lin. Nutr. 658S-665S.

9. de Pee S., Dary O. Biochemical indicators of vitamin A deficiency: serum retinol and serum retinol binding protein. J. Nutr. 2895S-2901S, 2002.

10. Mahmud MK, Hermana Zulfianto NA, Apriyantono RR, Ngadiarti I, Hartati, Bernadus, Tinexcelly. Tabel Komposisi Bahan Makanan. Jakarta, Elex Media Komputindo, 2008.

11. Pusat Penelitian dan Pengembangan Gizi. Program Nutrisoft. Bogor, Puslitbang Gizi, 2006.

12. Departemen Kesehatan. Angka Kecukupan Gizi ayng Dianjurkan bagi Bangsa Indonesia. Keputusan Menteri Kesehatan 
nomor 1593/Menkes/SK/XI/2005. Jakarta, 24 November 2005.

13. Erhardt JG, Estes JE, Pfeiffer CM, Biesalski HK, Craft NE. Combined measurement of ferritin, soluble transferrin receptor, retinol binding protein, and c-reactive protein by an inexpensive, sensitive, and simple sandwich enzyme-linked immunosorbent assay technique. J. Nutr. 134: 3127-3132, 2004.

14. Haskell MJ, Brown KH. Maternal vitamin A nutriture and the vitamin $A$ content of human milk. J Mammary Gland Biology and Neoplasia 4(3): 243-257, 1999.

15. UNICEF, 2007. Vitamin A supplementation: a decade of progress. UNICEF, New York.

16. Smith FR, Goodman DS, Zaklama MS, Gabr MK, el-Maraghy S, Patwardhan VN. Serum vitamin A, retinol-binding protein, and prealbumin concentrations in proteincalorie malnutrition. I. A function defect in hepatic retinol release. Am J Clin Nutr 26: 973-981, 1973.

17. Smith FR, Goodman DS, Arroyave G, Viteri F. Serum vitamin A, retinol-binding protein, and prealbumin concentrations in proteincalorie malnutrition. II. Treatment including supplemental vitamin A. Am J Clin Nutr 26: 982-987, 1973.

18. Ingenbleek $Y$, van den Schrieck $H G$, de Nayer $P$, de Visscher $M$. The role of retinolbinding protein in protein-calorie malnutrition. Metabolism 24: 633-641, 1975.
19. Semba RD, Yuniar Y, Gamble MV, Natadisastra G, Muhilal. Assessment of vitamin A status of preschool children in Indonesia using plasma retinol-binding protein. J Trop Pediatr 48: 84-87, 2002.

20. Gamble MV, Ramakrishnan R, Palafox NA, Briand K, Berglund L, Blaner WS. Retinol binding protein as a surrogate measure for serum retinol: studies in vitamin A-deficient children from the Republic of the Marshall Islands. Am J Clin Nutr 73: 594-601, 2001.

21. Almekinder J, Manda W, Soko D, Lan Y, Hoover DR, Semba RD. Evaluation of plasma retinol-binding protein as a surrogate measure for plasma retinol concentrations. Scand J Clin Lab Invest 60: 199-204, 2000.

22. de Pee S, Yuniar Y, West CE, Muhilal. Evaluation of biochemical indicators of vitamin A status in breast-feeding and nonbreastfeeding Indonesian women. Am J Clin Nutr 66: 160-167, 1997.

23. Baeten JM, Richardson BA, Bankson DD, Wener MH, Kreiss JK, Lavreys L, Mandaliya K, Bwayo JJ, McClelland RS. Use of serum retinol-binding protein for prediction of vitamin A deficiency: effects of HIV-1 infection, protein malnutrition, and the acute phase response. Am J Clin Nutr 79: 218-225, 2004. 
